\title{
19. PALEOCENE-EOCENE CALCAREOUS NANNOFOSSILS OF ONSHORE WELLS FROM THE COASTAL PLAIN OF NEW JERSEY AND MARYLAND, U.S.A. ${ }^{1}$
}

\author{
Yan Wen Jiang and Sherwood W. Wise, Jr., Department of Geology, Florida State University²
}

\begin{abstract}
Paleogene calcareous nannofossils from split spoon cores recovered from five wells along the Coastal Plain of New Jersey and Maryland have been analyzed in order to provide onshore information complementary to that derived from the offshore DSDP Site 605 (upper continental rise off New Jersey). Hiatuses are more numerous and of greater extent in the onshore sections, but the major ones correlate well with those noted in the offshore section. At one site at least (Leggett Well), sedimentation may well have been continuous across the Cretaceous/Tertiary boundary, as it is believed to have been at DSDP Site 605. These various correlations are discussed elsewhere in a companion paper (Olsson and Wise, this volume).

Important differences in nannofossil assemblages are noted between the onshore (shelf paleoenvironment) and offshore (slope-rise paleoenvironment) sections. Lithostromation simplex, not present offshore, is consistently present onshore and seems to be confined to the Eocene shelf sediments of this region. The same relationship holds for the zonal marker, Rhabdosphaera gladius Locker. The Rhomboaster-Tribrachiatus plexus is more diverse and better preserved in the onshore sections, where the lowermost Eocene Zone CP9 is well represented. Differential preservation is postulated to account for two morphotypes of Tribrachiatus bramlettei (Brönnimann and Stradner). Type A is represented at DSDP Site 605 by individuals with short, stubby arms, but these forms are not present in the equivalent onshore sections. There they are replaced by the Type B morphotypes, which exhibit a similar basic construction but possess much longer, more delicate arms.
\end{abstract}

\section{INTRODUCTION}

The recent advent of commercial petroleum exploration along the outer continental shelf of the eastern United States has stimulated intensive studies of the Mesozoic-Cenozoic history of this region, particularly in the area of the Baltimore Canyon Trough. In order to provide much needed drill data beyond the area of commercial exploration, DSDP Leg 93 (and subsequently DSDP Leg 95) emplaced a series of holes along the upper continental rise and slope southeast of Atlantic City, New Jersey, as part of the "New Jersey Transact." It was hoped that these DSDP holes would link outcrops and existing wells on land and along the continental shelf with those previously drilled in the deep sea to provide the first comprehensive downdip transect from the coastal plain to the abyssal plain. By correlating lithofacies and biofacies sequentially along the transect and by noting the presence of unconformities, their nature, age, correlation with seismic discontinuities, and relationships to sealevel fluctuations, it should be possible eventually to document in detail the upbuilding, outbuilding, and subsidence history of this passive margin.

If the goals outlined above are to be achieved, it will be necessary to provide data from the coastal plain equivalent in nature to that being made available from offshore. Correlations will naturally be more precise if the same microfossil groups are reported for both areas. In

\footnotetext{
${ }^{1}$ van Hinte, J. E., Wise, S. W., Jr., et al., Init. Repts. DSDP, 93: Washington (U.S. Govt. Printing Office).

(We) Department of Geology, Florida State University, Tallahassee, FL 32306; Jiang (current address) Department of Geology, Jianghan Petroleum College, Jiangling, Hubei 934102 , People's Republic of China.
}

practice, however, some disparity exists in the available data sets, in that some microfossil groups traditionally relied on in the pelagic realm are not necessarily those which have been applied most intensively in onshore studies. For the New Jersey region, the calcareous nannofossils are a case in point. Although nannofloras of selected Campanian-Maestrichtian samples have been examined in studies by Worsley (1974), Sissingh (1977), Wind (1979), and Hattner et al. (1980), the most detailed microfossil work in New Jersey has been carried out by foraminiferal specialists, particularly by Olsson and his colleagues (Olsson, 1964, 1970; Petters, 1977a, b; Olsson and Nyong, 1984; and Nyong and Olsson, 1984). Additional correlations have been made between the dinoflagellate and planktonic foraminiferal biostratigraphies of the New Jersey Cretaceous sequences (Koch and Olsson, 1977; Aurisano, 1984). Detailed comparisons of Tertiary nannofossil data between the New Jersey onshore and offshore sections, however, are not possible until the coccoliths of the coastal plain sections are better studied.

In order to augment the available nannofossil data from New Jersey and its environs, we provide here range charts for Paleogene well samples (split spoon cores) which have previously been studied or are currently being studied by Olsson and his colleagues (see Fig. 1 for locations). The wells had been cored at designated intervals using the split spoon device, and all were rotary drilled except for the Point Pleasant well, which was bored by cable tools. The range charts provide data which are used elsewhere in these Initial Reports, particularly in the regional synthesis by Olsson and Wise (this volume) of Campanian-Eocene strata in the Baltimore Canyon area. Limited comments and comparisons between these on- 


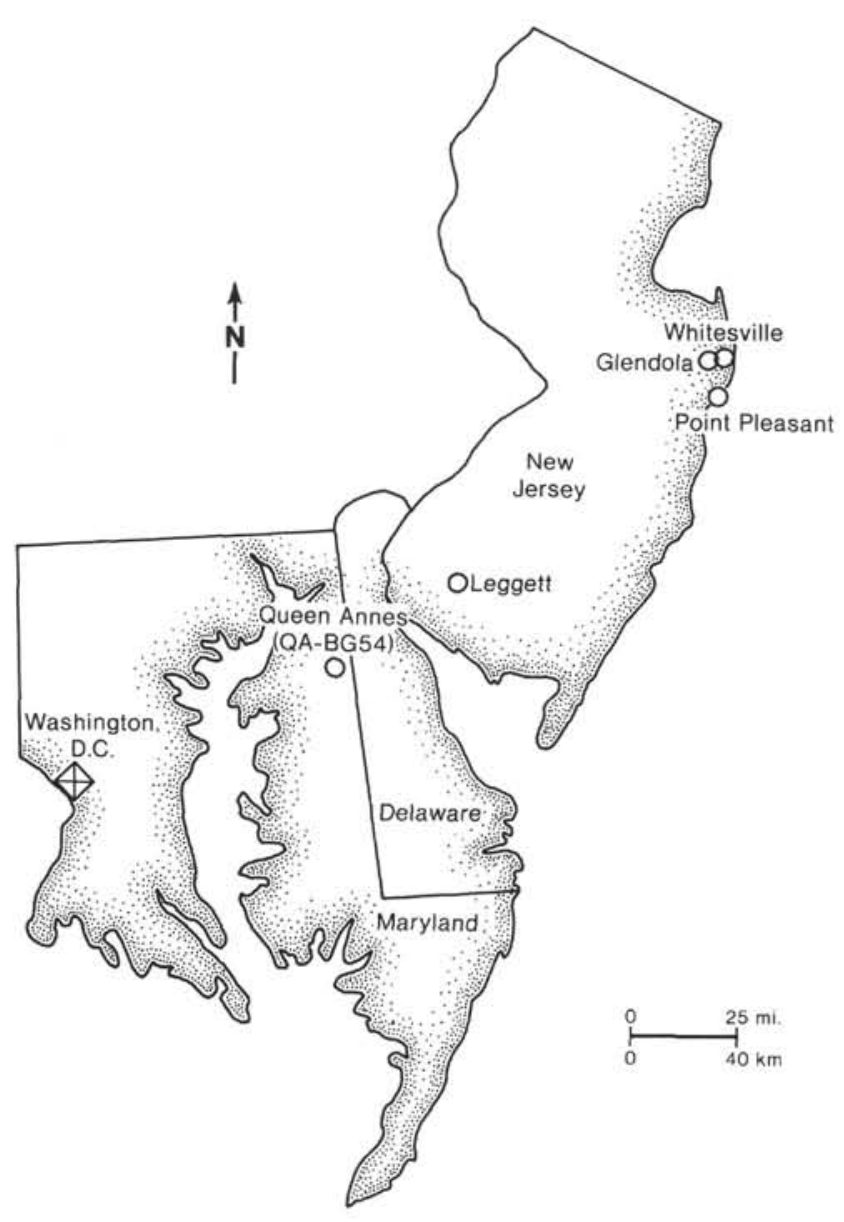

Figure 1. Locations of wells used in this study.

shore nannofossil assemblages and those described from the offshore DSDP Leg 93 Site 605 (Lang and Wise, this volume; Applegate and Wise, this volume) are included herein.

\section{METHODS, ZONATION, AND SPECIES CONSIDERED}

The generally rich nannoflora found in samples examined from the coastal plain of the New Jersey greatly facilitated the preparation of samples for observation in the light microscope. Smear slides were prepared directly from raw sediment in order to examine the true abundances of coccoliths and other nannoliths.

The species abundances are described using a format similar to that outlined by Hay (1970), except that the standard smear slides were examined at $\times 625$, rather than at $\times 1000$ as suggested by Hay. The format used is as follows:

$\mathrm{R}=$ rare; 1 specimen in 101-1000 fields of view.

$\mathrm{F}=$ few; 1 specimen in $11-100$ fields of view.

$\mathrm{C}=$ common; 1 specimen in 2-10 fields of view.

$\mathrm{A}=$ abundant; $1-10$ specimens per field of view.

Downhole contaminants, which are common in some samples, are denoted by lowercase letters.

A qualitative description of the preservation of nannofossils is provided using a scheme modified from Lang and Watkins (1984). Our scheme is the following:

$\mathrm{VG}=$ very good; no evidence of secondary alteration via etching and/or overgrowth.

$\mathrm{G}$ = good; little evidence of secondary alteration via etching and/ or overgrowth, identification of species not impaired.

$\mathbf{M}=$ moderate; significant evidence of secondary alteration via etching and/or overgrowth, identification of species not impaired.
$\mathrm{P} \quad=$ poor; specimens typically heavily overgrown or severely etched, identification of some species significantly impaired.

The Cenozoic zonation of Okada and Bukry (1980) is applied in this study (Fig. 2). Taxa considered in this report are listed in the Appendix, where they are arranged alphabetically by specific epithets. Citations for these species are provided in the "Annotated index and bibliography of the calcareous nannoplankton, I-VII" (Loeblich and Tappan, 1966; 1968; 1969; 1970a, b; 1971; 1973) and from the "Bibliography and taxa of calcareous nannoplankton" (van Heck, 1979a, b; 1980a, b; 1981a, b; 1982a, b; 1983).

Mesozoic samples below the Cretaceous/Tertiary contact in each well were not examined in detail. The Mesozoic samples, therefore, are not zoned.

\section{NANNOFOSSIL STRATIGRAPHY OF COASTAL PLAIN WELLS}

\section{Leggett Well, New Jersey (Table 1)}

Figure 1 shows the location of the Leggett Well in southern New Jersey. Also known as the E.I. Dupont test well No. 2, this well was spudded at Willow Grove in Cumberland County. Split spoon samples were taken at $10-\mathrm{ft}$. intervals. This method of sampling does not provide continuous core coverage. Worsley (1974, appendix I) listed 5 Cretaceous samples from this well; he provided no information on their nannofossil content in that paper, but had earlier provided a tentative zonation for the interval from $630-750 \mathrm{ft}$. (personal communication to R. K. Olsson, 24 March 1970). The dinoflagellate and planktonic foraminiferal biostratigraphies of the Danian-Maestrichtian portion of this well were reported by Koch and Olsson (1977).

Worsley (1970, personal communication to R. K. Olsson) placed Sample 700 in the uppermost Cretaceous Nephrolithus frequens Zone and suggested that Sample 690 was "probably the Cruciplacolithus tenuis Zone." He then placed samples from $630-680 \mathrm{ft}$. in the Discoaster multiradiatus Zone.

Our results are quite similar to those of Worsley, including confirmation of the $N$. frequens Zone in Sample 700 (Table 1). It is quite probable that sedimentation at this site was continuous or nearly so across the Cretaceous/Tertiary boundary, as indicated by Worsley's initial results. This seems apparent despite the 10 -ft. sample spacing for this well.

We did note, however, what appears to be the mixture of two assemblages in our cut of Sample 690. These consist of few Zygodiscus sigmoides and rare C. tenuis on the one hand, and abundant Heliolithus kleinpellii (plus common $H$. riedelii) on the other. One interpretation is that the split spoon sample taken at the bottom of interval $680-690 \mathrm{ft}$. could have sampled more than one stratum, perhaps in the configuration shown in Figure 3. Nevertheless, it is evident that the interval from CP5 to CP7 is represented by only a short interval in this well.

The Paleocene/Eocene boundary lies just below Sample 600 , which contains a surprisingly diverse assemblage of Tribrachiatus and Rhomboaster. Tribrachiatus contortus and T. bramlettei were recorded offshore at DSDP Site 605 (Applegate and Wise, this volume), but not Rhomboaster cuspis and $R$. bitrifida. We did not observe in our onshore sections the stubby $T$. bramlettei seen at Site 605. Instead, a form with a similar construc- 


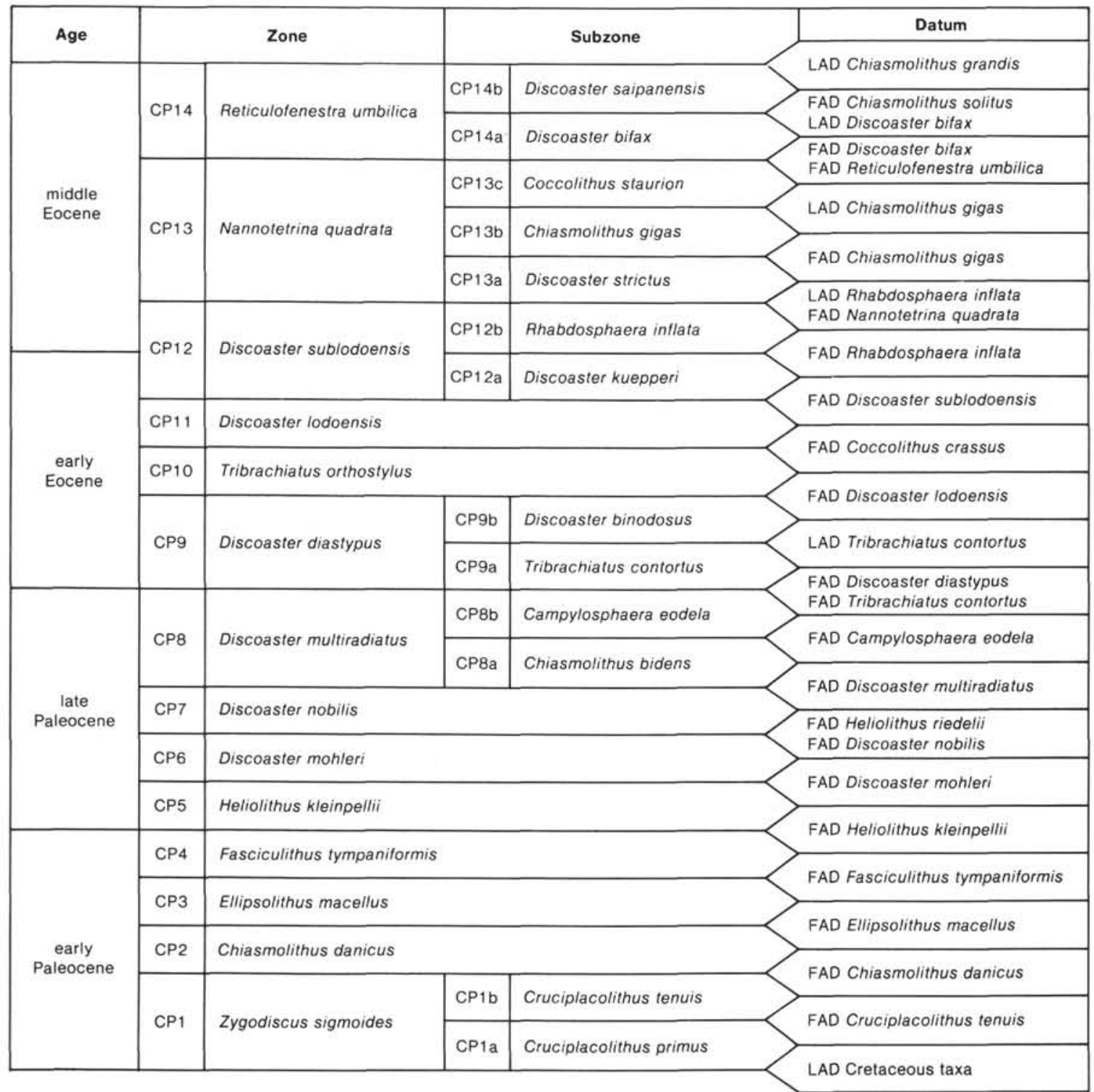

Figure 2. Zonation used in this study (from Okada and Bukry, 1980).

tion but much longer arms is present (compare Fig. 5 of this chapter, later, with Pl. 2, Figs. 8-9 of Applegate and Wise, this volume). We label this long-rayed form " $T$. bramlettei (type B)" on our range charts. We believe this is the same taxon represented at the offshore Site 605 , and that the difference in morphotypes is preservational (see further discussion later under "Taxonomic Notes").

Romein (1979) indicates that the various taxa of Rhomboaster and Tribrachiatus mentioned above are confined to the uppermost Paleocene-lowermost Eocene. We have not confirmed our identifications using the electron microscope, but the long overlap of $50 \mathrm{ft}$. between the ranges of Discoaster multiradiatus and the species of Rhomboaster and Tribrachiatus just cited suggest extensive deposition in this region during the earliest Eocene. The basal Eocene nannofossil zone, CP9, encompasses 50 $\mathrm{ft}$. of section in this well.
The base of Zone CP10 is somewhat uncertain because $D$. lodoensis occurs sporadically from Sample 540 upward. These lower occurrences may represent downhole contamination. If these are not contaminants, then Subzone CP9b (the $D$. binodosus Subzone) would be missing at this locality, and a hiatus would be suspected between 540 and $550 \mathrm{ft}$. If these are contaminants, the boundary should be placed below $490 \mathrm{ft}$, where $D$. lodoensis becomes abundant and occurs consistently.

Discoaster sublodoensis is present only in Sample 480, which indicates that most of Zone CP12 is missing, probably through a hiatus. At Site 605, this zone encompasses $86.7 \mathrm{~m}$ of section (Applegate and Wise, this volume).

A most interesting observation is the consistent occurrence of Lithostromation simplex from Sample 460 to the top of the reported section. This taxon was not present offshore (Applegate and Wise, this volume) and therefore seems to have been confined to the shelf envi- 
Table 1. Distribution of calcareous nannofossils, Leggett Well, New Jersey Coastal Plain.

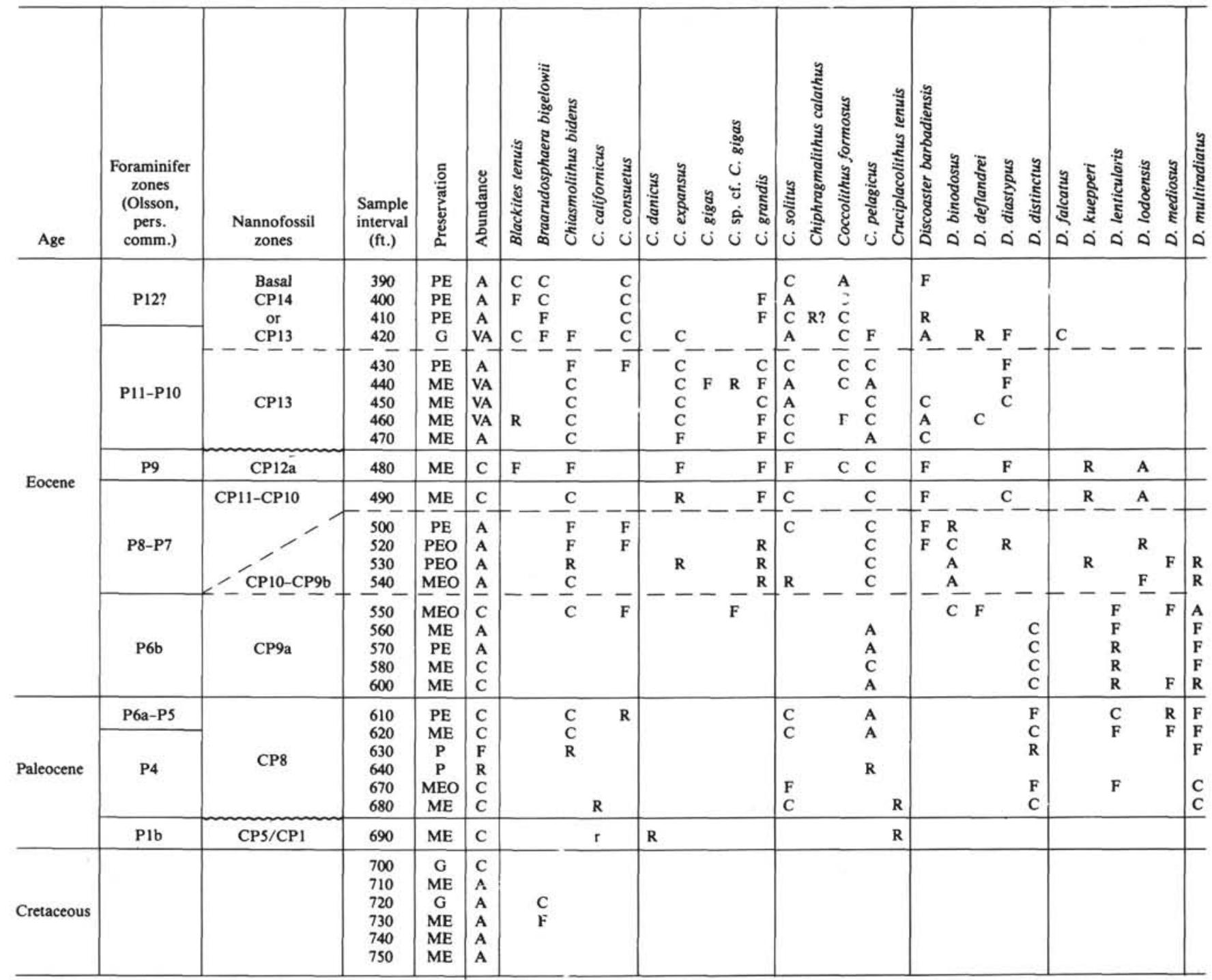

Note: Abundance is characterized by VA, very abundant; C, common; F, few; R, rare; B, barren, EB, essentially barren. For preservation, P, poor; M, moderate; G, good, E, etched; $\mathrm{O}$, overgrown. Lowercase letters indicate material considered to be reworked.

ronment of this region, beginning around the boundary between early and middle Eocene time.

Another interesting occurrence is the rare but well documented occurrence of Rhabdosphaera gladius in Sample 420 (Fig. 4). This taxon, not observed at Site 605 or in most other deep-sea sections, has a short range which terminates just within (Bukry, 1978) or just at the base (Perch-Nielsen, 1985) of CP14. In the Leggett Well, it co-occurs with the first Reticulofenestra umbilica, which marks the base of CP14. The sequence here appears much as Bukry (1978) suggested it would, in that Chiasmolithus gigas (mid CP13) occurs farther down in the section in Sample 440. This sequence is not so straightforward offshore at DSDP Site 605, however, where $C$. gigas and Reticulofenestra umbilica overlap over some $53.1 \mathrm{~m}$ of section (Applegate and Wise, this volume).

\section{Whitesville Well, New Jersey (Table 2)}

The Whitesville Well was cored just east of Asbury Park, New Jersey (elevation, 20 ft.). Nannofossils are ab- sent in the lowest Paleocene sample above the Cretaceous contact, and those in the succeeding two samples are characteristically few. Sample 238-260 contains rare Cruciplacolithus tenuis and Zygodiscus sigmoides in the absence of any chiasmoliths or fasciculiths, and is therefore assigned to Zone CP1. Sample 225-238 may belong to Zone CP3.

Heliolithus kleinpellii is abundant beginning in Sample $220-225$ and is consistently present through Sample $175-180$, a range of $50 \mathrm{ft}$. This is in contrast to its confinement to less than a 10-ft. interval in the Leggett Well. Rare to few $H$. riedelii in three of the lower samples are probably contaminants, but this taxon is consistently present from Sample 175-180 to 154-160, where it is common to abundant in three samples. The lowest occurrences of $D$. mohleri are probably also contaminants. For purposes of zonation, we would consider most reliable the higher, more consistent occurrences of these taxa, thereby leaving open to question the exact placement of the interval from Samples 210-205 to 180-185. 
Table 1 (continued).

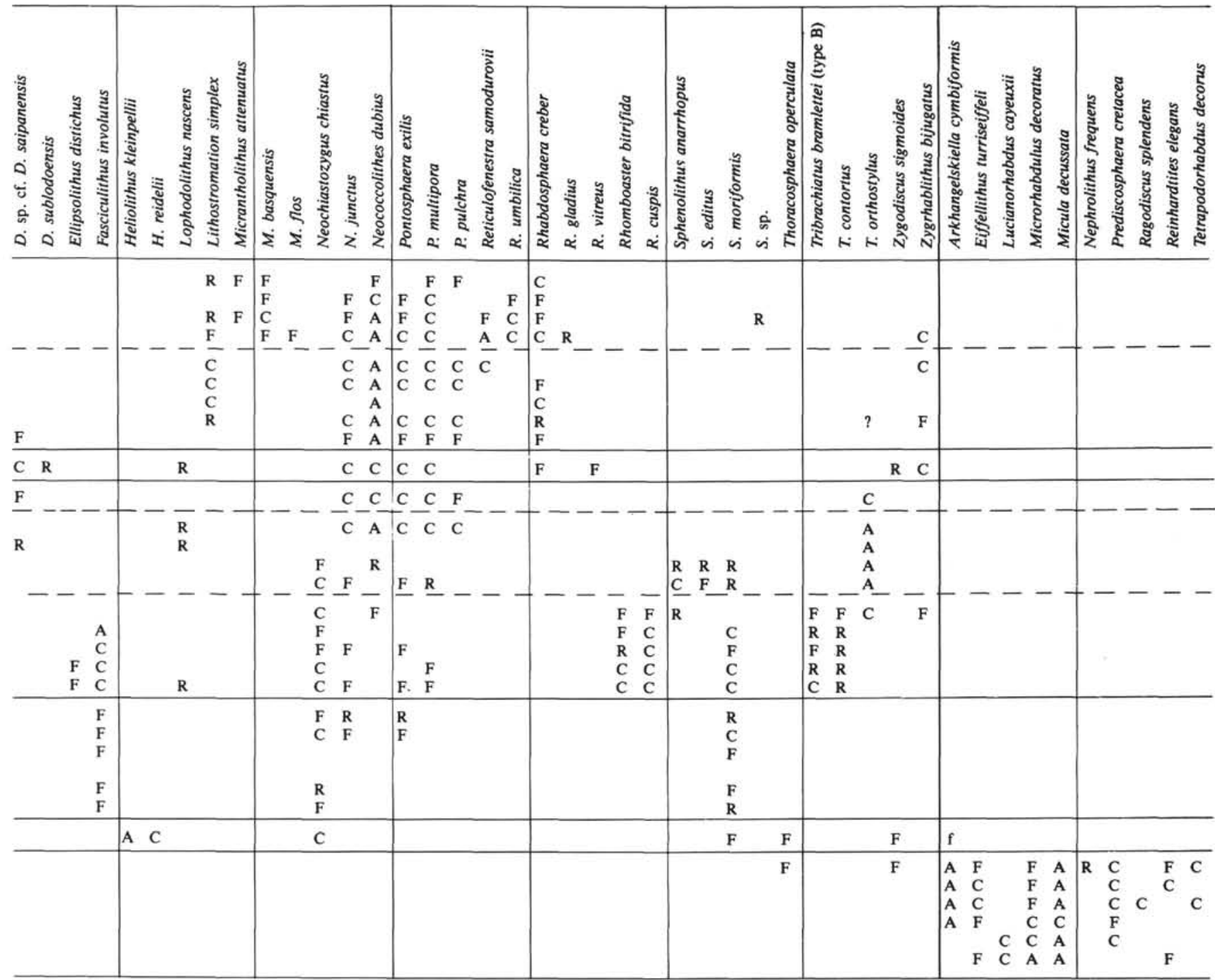

Discoaster multiradiatus is only encountered in few to rare numbers beginning in Sample 149-154 ft. Coccoliths are few in the two overlying samples where $D$. $m u l$ tiradiatus occurs mixed with lower and middle(?) Eocene forms such as Chiasmolithus grandis and Neococcolithes dubius. This indicates downhole contamination within the well, a fact illustrated by the presence of $C$. grandis as far down as Sample 210-215 and D. kuepperi in Samples 149-154 and 154-160. It is, of course, not always possible to distinguish downhole contamination as opposed to reworking upward in a sequence such as this. It is possible that the topmost two samples belong to the Eocene Zone CP9. Indeed, the youngest sample $(106-127 \mathrm{ft})$ is assigned to the Eocene on the basis of planktonic foraminifers (R. K. Olsson, personal communication, 1986). We place the boundary one sample lower on the basis of rare Tribrachiatus orthostylus, but these specimens could be contaminants.

\section{Glendola Well, New Jersey (Table 3)}

The Glendola Well was cored at a location about $1.5 \mathrm{mi}$. northwest of the town of Glendola, New Jersey (elevation, $100 \mathrm{ft}$ ). The Paleocene sequence is somewhat similar to that in the Whitesville Well, but preservation is not as good.

Nannofossils are rare and poorly preserved in the first two samples above the Cretaceous contact. There is no indication among the nannofossils that the lowermost Paleocene was sampled; however, there is a long (67 ft.) sequence containing Heliolithus kleinpellii, which gives way to $H$. riedelii after a one-sample overlap. Discoaster mohleri is again sparse, making the identification of its lowest occurrences uncertain. As in the Whitesville Well, it seems to occur most consistently with $H$. riedelii. Apparently, Zones CP6 and CP7 are present in the section, which was not sampled continuously.

After a barren interval between 194 and $206 \mathrm{ft}$., $D$. multiradiatus is common and consistently present along with species of Rhomboaster and Tribrachiatus. Lower Eocene planktonic foraminifers occur in these samples (R. K. Olsson, personal communication, 1986); therefore, all are assigned somewhat arbitrarily to CP9. Without the foraminiferal data, Sample 184-186 would have been assigned to $\mathrm{CP} 8$, and the Paleocene-Eocene bound- 
Table 2. Distribution of calcareous nannofossils, Whitesville Well, New Jersey Coastal Plain.

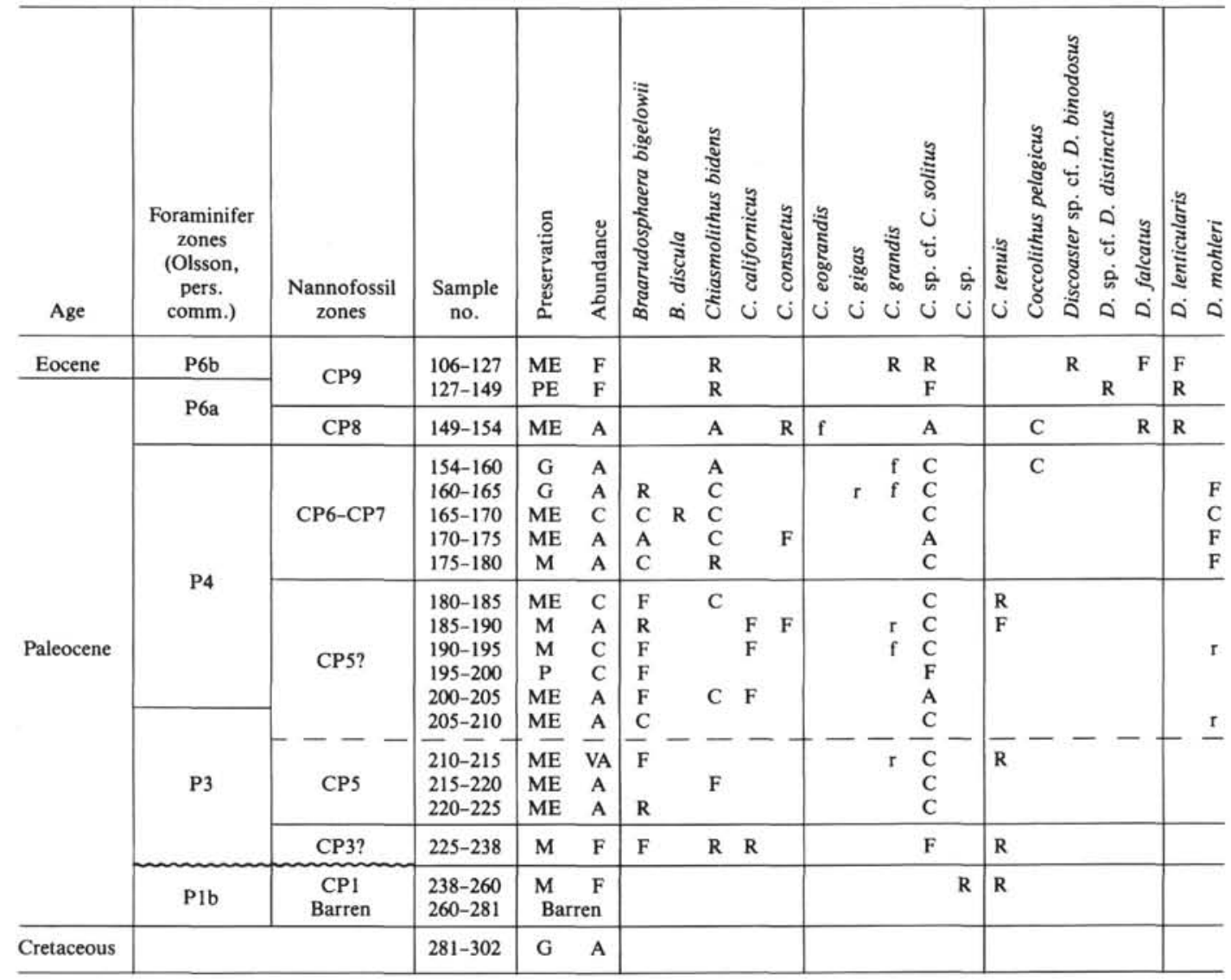

Note: Abundance is characterized by VA, very abundant; C, common; F, few; R, rare; B, barren, EB, essentially barren. For preservation, P, poor; M, moderate; G, good, E, etched; O, overgrown. Lowercase letters indicate material considered to be reworked.

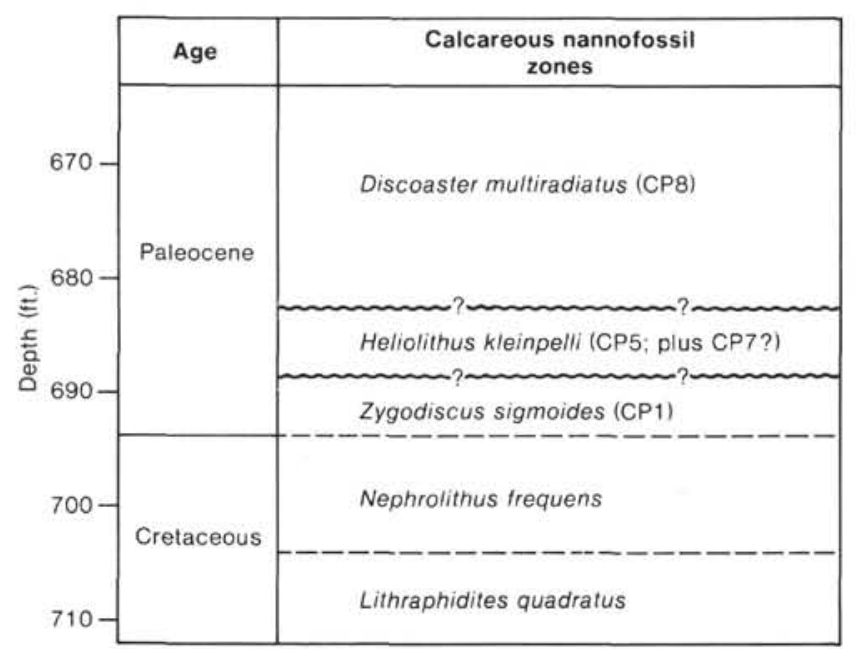

Figure 3. Interpretation of the stratigraphic sequence sampled in the Leggett Well by the split spoon cores across the interval 680-690 ft. At least two separate zones (CP1 and CP5) seem to have been sampled by the core taken at $690 \mathrm{ft}$. Sedimentation was probably continuous across the Cretaceous/Tertiary boundary, but disconformities appear to separate the CP5 zonal interval from strata above and below.
A
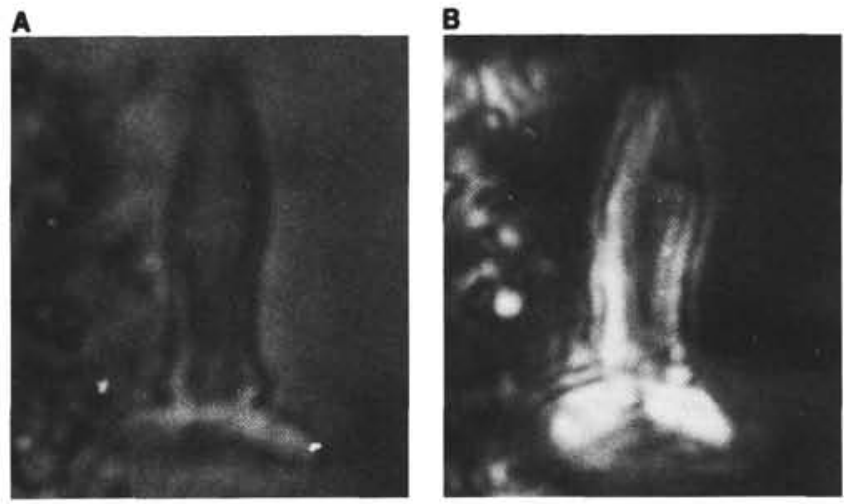

Figure 4. Rhabdosphaera gladius Locker, $\times 3400$, Leggett Well, Sample 420, (A) cross-polarized light, (B) transmitted light.

ary based on nannofossils would have been drawn slightly higher, closer to the FADs in this section of T. bramlettei (type B) (Sample 179-180) and of D. diastypus (Sample 174-175), datums used by Martini (1971) and Bukry (1978), respectively, to approximate that boundary.

The FADs of $D$. lodoensis and $D$. kuepperi coincide in Sample 159-161 to mark the base of CP10. The LAD of $D$. binodosus is taken as a very rough approximation of the top of CP10 (by comparison with its occurrence at Site 605). 
Table 2 (continued).

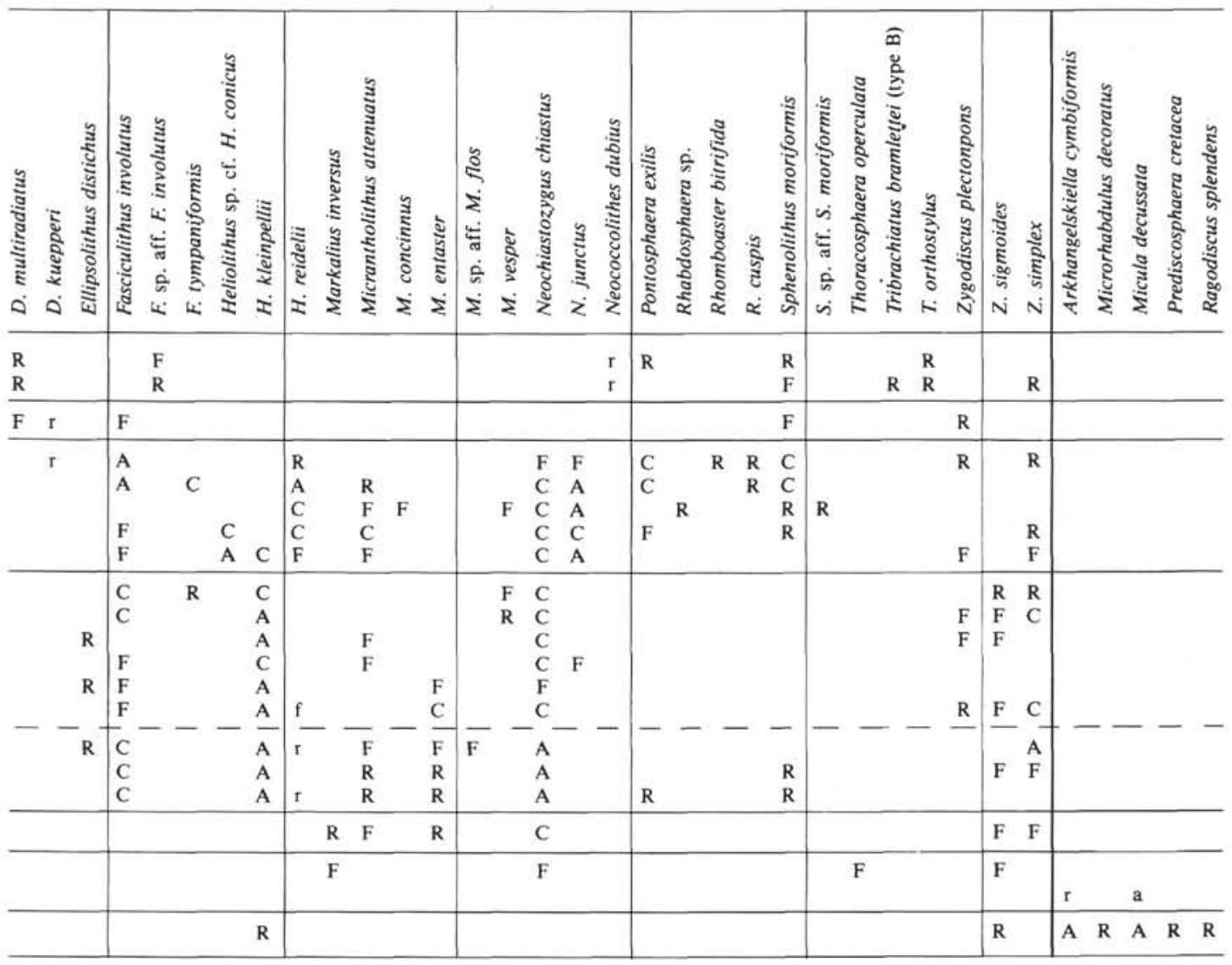

The absence in this well of $D$. sublodoensis, which is few to common but consistently present at Site 605, suggests a significant hiatus, which we place between Samples 124-125 and 119-120. This would account for the simultaneous disappearances upsection of $D$. lodoensis and $T$. orthostylus. We believe that most of CP11, all of $\mathrm{CP} 12$, and most of $\mathrm{CP} 13$ are missing, even taking into account the 5 -ft. sampling gaps in this portion of the section.

Lithostromation simplex is again noted and is common in the topmost two samples. CP14 may be represented by Sample 114-115, which contains rare Reticulofenestra umbilica. It should be remembered, however, that this taxon was consistently present in the upper CP13 Zone at DSDP Site 605, where it overlapped Chiasmolithus gigas over a long interval. Unfortunately, neither $C$. gigas nor Nannotetrina quadrata are recorded in the Glendola Well, so it is difficult to delimit CP13, which we relegate to one sample.

\section{Point Pleasant Well, New Jersey (Table 4)}

The Point Pleasant Well was located in the town of Point Pleasant, New Jersey (elevation, $20 \mathrm{ft}$.). The well was bored and sampled by cable tool. As one might expect with this type of sampling, there is a significant amount of downhole contamination which complicates the interpretation of the section. For this reason, more reliance is placed on LADs than on FADs for drawing zonal boundaries.
The first sample above the Cretaceous contact is barren. The succeeding sample contains few coccoliths, and cannot be reliably dated, but may be CP1 if the rare Chiasmolithus bidens noted is a downhole contaminant. The next two samples contain few or rare Fasciculithus involutus and Heliolithus kleinpellii, which, if not downhole contaminants, would indicate Zone CP5. This assignment is supported by a rare specimen of Discoasteroides bramlettei in Sample 525. Common H. kleinpellii and $H$. riedelii co-occur in Sample 515, which suggests CP7. Discoaster mohleri is absent, so CP6 may well be missing in this section. The interval containing H. kleinpellii is only $20 \mathrm{ft}$. at most, far less than in the Whitesville and Glendola wells. The next $50 \mathrm{ft}$. are barren.

A diverse flora is encountered beginning with Sample 435 , but much of this could be due to downhole contamination. D. multiradiatus is abundant in Sample 415, but is rare to few in the two samples below, where Tribrachiatus orthostylus is abundant. Such a reversal in dominance between these genera is unusual, but was recorded previously in Sample 550 from the Leggett Well (Table 1).

Ellipsolithus macellus occurs in unusual numbers, being abundant in Samples 435, 425, and 395. This taxon was not observed in any of the other onshore well sections, but was consistently present in Zones CP9 and CP10 at the offshore Site 605 (Applegate and Wise, this volume).

The base of CP10 could be placed around $375-285 \mathrm{ft}$., where $D$. lodoensis and $D$. kuepperi become reasonably 
Table 3. Distribution of calcareous nannofossils, Glendola Well, New Jersey Coastal Plain.

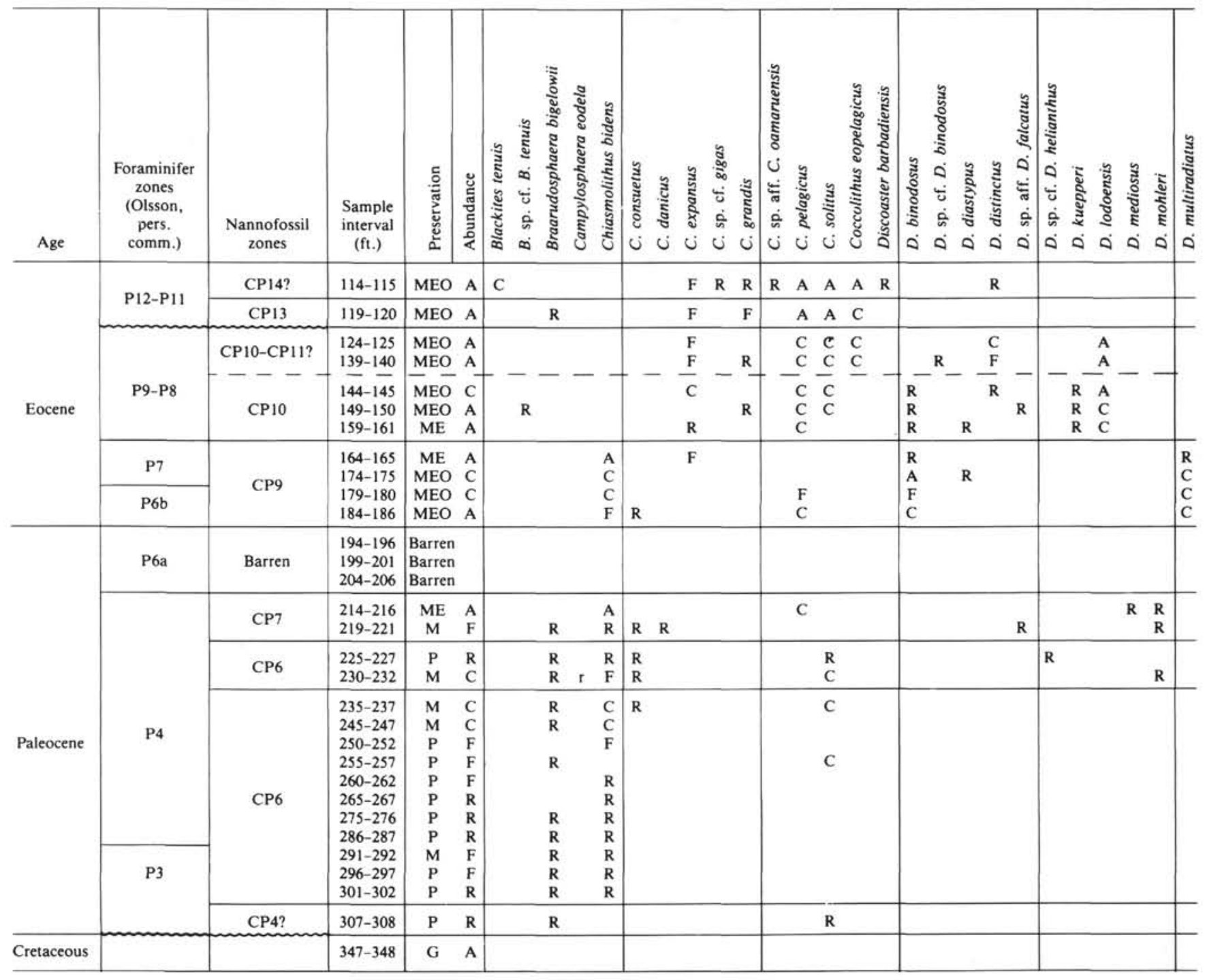

Note: Abundance is characterized by VA, very abundant; C, common; F, few; R, rare; B, barren, EB, essentially barren. For preservation, P, poor; M, moderate; G, good, $\mathrm{E}$, etched; $\mathrm{O}$, overgrown. Lowercase letters indicate material considered to be reworked.

consistent in their occurrence. This zone, however, could extend as far downsection as Sample 405 if the possibility of downhole contamination of the taxa is discounted. Also present are few Chiphragmalithus calathus, which occur at about this level in DSDP Hole 605. The CP10 boundary can only be approximated in that the presence of few to common Reticulofenestra umbilica in this interval indicates serious downhole contamination problems. The LAD of T. orthostylus is used to approximate the top of CP11. Rare occurrences of D. sublodoensis and Nannotetrina quadrata are ignored in light of the downhole contamination problem. The LADs of $D$. kuepperi and $D$. lodoensis restrict Sample 315 to CP12a or below. Section could be missing here if the hiatus noted in the Glendola Well extends to this locality. R. umbilica is consistently present above Sample 285; in the lower samples $(275,285)$ it is accompanied by common Lithostromation simplex.
As indicated previously, this zonation of the Point Pleasant Well cannot be considered very satisfactory in view of the considerable downhole contamination problems, which apparently resulted from the cable tool method of drilling the hole.

\section{Maryland Well QA-BG54 (Table 5)}

Samples from Well QA-BG54 (eastern shore of Maryland) were examined in order to characterize the Paleocene interval at this locality. The well is located in Queen Annes County, Maryland, just east of Unicorn (elevation approximately $60 \mathrm{ft}$.).

The well yielded an extensive sequence ( $33 \mathrm{ft}$.) assigned to CP1. Common Chiasmolithus bidens in the absence of fasciculiths assign Sample 249-250 to CP3. The overlying sample (245-247) contains few Fasciculithus involutus and rare Heliolithus riedelii, and could be assigned to Zones CP4 to CP7. Planktonic foraminiferal studies 
Table 3 (continued).

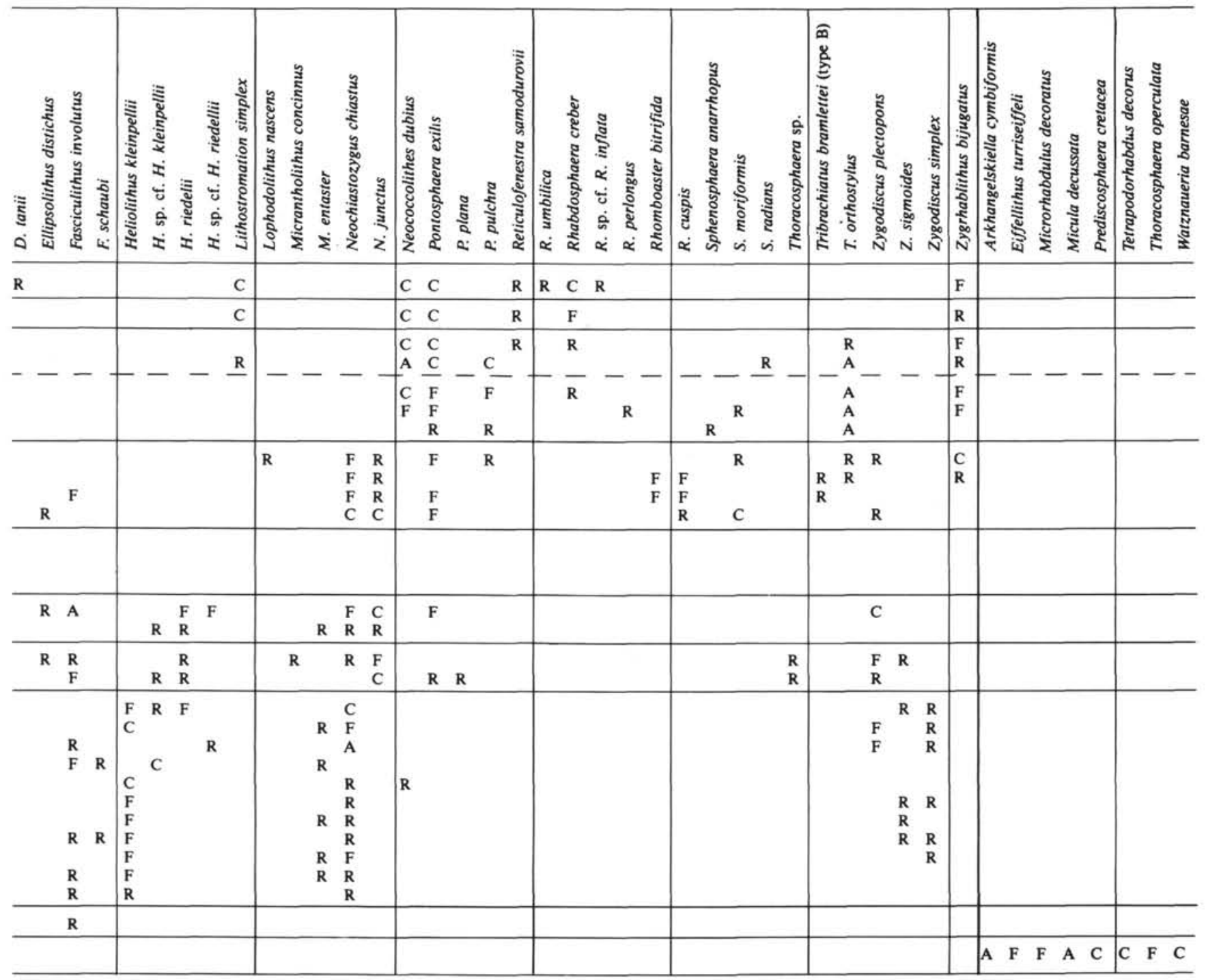

suggest that CP4 is correct (R. K. Olsson, personal communication, 1986). The rare $H$. riedelii in the sample, therefore, should be considered a downhole contaminant.

\section{TAXONOMIC NOTES}

Tribrachiatus bramlettei (Brönnimann and Stradner) Proto Decima et al., 1975 (morphotype B) (Fig. 5)

Remarks. Tribrachiatus bramlettei is traditionally regarded as a species of Tribrachiatus which consists of two superimposed triangular blocks centered symmetrically one above the other, but oriented in opposite directions. Applegate and Wise illustrate such a form from DSDP Hole 605 on the upper continental rise off New Jersey (this volume, Pl. 2, Figs. 8-9), where the taxon was few but consistently present over a 3-m interval. No such forms were observed in equivalent onshore strata analyzed in the present chapter. Instead, similarly constructed but longer-rayed individuals were present (Fig. 5). The opposed triangular units of these specimens are centered one above the other without significant offset where the rays converge; thus these specimens belong to the genus Tribrachiatus rather than Rhomboaster (sensu Romein, 1979).

Because the onshore and offshore specimens are stratigraphically equivalent and are of similar construction, differing only by the lengths of their rays, we consider them one and the same species. We believe the variation in ray length between the onshore versus offshore specimens is due to preservation. The section at DSDP Site 605 is more calcareous and has suffered extensive diagenesis in the way of dissolution and overgrowth of nannofossils (Applegate and Wise, this volume). Preservation is considerably better in the more siliceous sediments of the Coastal Plain, where overgrowths are far less noticeable and the chances of preserving more delicate structures are considerably enhanced (see Wise, 1977, for a discussion of factors that affect diagenesis of nannofossils).

Following the argument stated above, we distinguish two morphotypes of Tribrachiatus bramlettei. The stubby form represented in the offshore at DSDP Site 605 is labeled morphotype A. The long-rayed form prevalent in the New Jersey Coastal Plain sections is labeled morphotype B.

\section{ACKNOWLEDGMENTS}

We are indebted to Professor Richard K. Olsson (Rutgers University, New Brunswick, N.J.), who suggested the study and provided all samples used. In addition, he supplied the complementary planktonic foraminiferal data and lithologic descriptions, and suggested ways in which these data could be correlated with the nannofossil information. The range charts were constructed by the first author during a year in residence at FSU. We thank Mr. John Firth (FSU) for spotting Nephrolithus frequens in Leggett Sample 700, and Mr. Wuchang Wei 
Y. W. JIANG, S. W. WISE, JR.

Table 4. Distribution of calcareous nannofossils, Point Pleasant Well, New Jersey Coastal Plain.

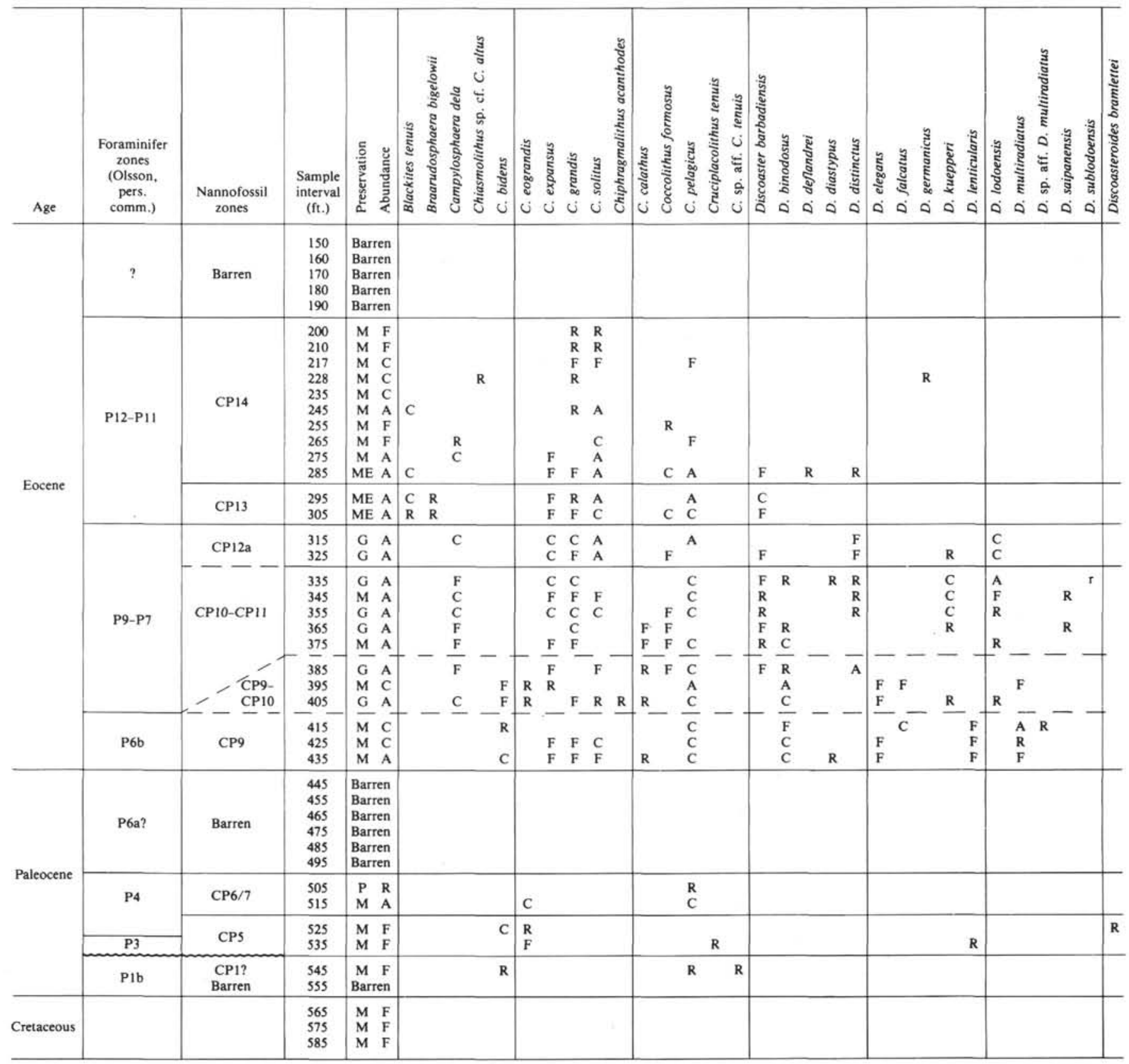

Note: Abundance is characterized by VA, very abundant; C, common; F, few; R, rare; B, barren, EB, essentially barren. For preservation, F, poor; M, moderate; G, good, E, etched; O, overgrown. Lowercase letters indicate material considered to be reworked.

(FSU) for his helpful assistance in preparing the manuscript. Laboratory support provided by NSF Grant 84-14268.

\section{REFERENCES}

Aurisano, R. W., 1984. Three new dinoflagellate species from the subsurface Upper Cretaceous Atlantic Coastal Plain of New Jersey. $J$. Paleontol., 58:1-8.

Bukry, D., 1978. Biostratigraphy of Cenozoic marine sediment by calcareous nannofossils. Micropaleontology, 24:44-60.

Hattner, J. B., Wind, F. H., and Wise, S. W., 1980. The Santonian/ Campanian boundary: comparison of nearshore-offshore calcareous nannofossil assemblages. Cah. Micropaleontol., 3:9-26.

Hay, W. W., 1970. Calcareous nannofossils from cores recovered on Leg 4. In Bader, R. G., Gerard, R. D., et al., Init. Repts. DSDP, 4: Washington (U.S. Govt. Printing Office), 455-501.
Heck, S. E. van, 1979a. Bibliography and taxa of calcareous nannoplankton. Int. Nannoplankton Assoc. Newsl., 1:AB1-5, A1-12, B1-27.

1979b. Bibliography and taxa of calcareous nannoplankton. Int. Nannoplankton Assoc. Newsl., 1:AB VI, A13-28, B2842.

1980a. Bibliography and taxa of calcareous nannoplankton. Int. Nannoplankton Assoc., Newsl., 2:5-34.

1980b. Bibliography and taxa of calcareous nannoplankton. Int. Nannoplankton Assoc. Newsl., 2:43-81.

1981a. Bibliography and taxa of calcareous nannoplankton. Int. Nannoplankton Assoc. Newsl., 3:4-41.

1981b. Bibliography and taxa of calcareous nannoplankton. Int. Nannoplankton Assoc. Newsl., 3:51-86.

, 1982a. Bibliography and taxa of calcareous nannoplankton. Int. Nannoplankton Assoc. Newsl., 4:7-50. 
Table 4 (continued).

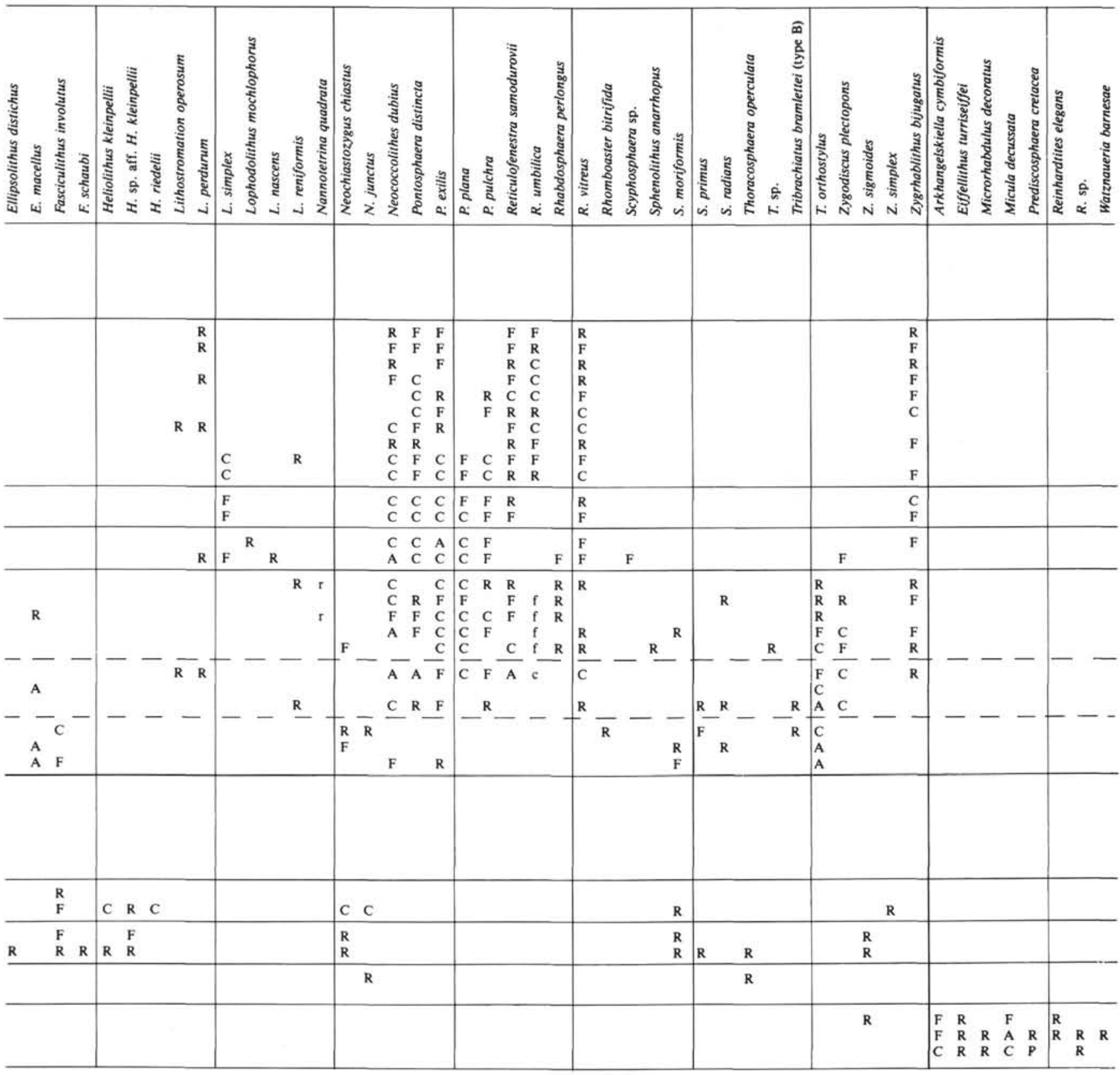

,1982b. Bibliography and taxa of calcareous nannoplankton. Int. Nannoplankton Assoc. News., 4:65-96.

1983. Bibliography and taxa of calcareous nannoplankton. Int. Nannoplankton Assoc. Newsl., 5:4-13.

Koch, R. C., and Olsson, R. K., 1977. Dinoflagellate and planktonic foraminiferal biostratigraphy of the uppermost Cretaceous of New Jersey. J. Paleontol., 51:480-491.

Lang, T. H., and Watkins, D. K., 1984. Cenozoic calcareous nannofossils from Deep Sea Drilling Project Leg 77: Biostratigraphy and delineation of hiatuses. In Buffler, R. T., Schlager, W., et al., Init. Repts. DSDP, 77: Washington (U.S. Govt. Printing Office), 629648.

Loeblich, A. R., Jr., and Tappan, H., 1966. Annotated index and bibliography of the calcareous nannoplankton, I. Phycologia, 5:81216.

1968. Annotated index and bibliography of the calcareous nannoplankton, II. J. Paleontol., 42:584-598.
1969. Annotated index and bibliography of the calcareous nannoplankton, III. J. Paleontol., 43:568-588.

1970a. Annotated index and bibliography of the calcareous nannoplankton, IV. J. Paleontol., 44:558-574.

$1970 \mathrm{~b}$. Annotated index and bibliography of the calcareous nannoplankton, V. Phycologia, 9:157-174.

1971. Annotated index and bibliography of the calcareous nannoplankton, VI. Phycologia, 10:315-339.

1973. Annotated index and bibliography of the calcareous nannoplankton, VII. J. Paleontol., 47:715-759.

Martini, E., 1971. Standard Tertiary and Quaternary calcareous nannoplankton zonation. In Farinacci, A. (Ed.), Proc. II Planktonic Conf. Roma (Vol. 2): Rome (Edizioni Tecnoscienza), 739-785.

Nyong, E. E., and Olsson, R. K., 1984. A paleoslope model of Campanian to lower Maestrichtian foraminifera in the North American Basin and adjacent continental margin. Mar. Micropaleontol., 8: 437-477. 
Okada, H., and Bukry, D., 1980. Supplementary modification and introduction of code numbers to the low-latitude coccolith biostratigraphic zonation (Bukry, 1973; 1975). Mar. Micropaleontol., 5:321325.

Olsson, R. K., 1964. Late Cretaceous planktonic foraminifers from New Jersey and Delaware. Micropaleontology, 10:157-188.

1970. Paleocene planktonic foraminiferal biostratigraphy and paleozoogeography of New Jersey. J. Paleontol. 44:587-597.

Olsson, R. K., and Nyong, E. E., 1984. A paleoslope model for Campanian-lower Maestrichtian foraminifera of New Jersey and Delaware. J. Foraminiferal Res., 14:50-68.

Perch-Nielsen, K., 1985. Cenozoic calcareous nannofossils. In Bolli, H. M., Saunders, J. B., and Perch-Nielsen, K. (Eds.), Plankton Stratigraphy: Cambridge, England (Cambridge University Press), pp. 427-554.

Petters, S. W., 1977a. Bolivinoides evolution and Upper Cretaceous biostratigraphy of the Atlantic Coastal Plain of New Jersey. J. Paleontol., 51:1023-1036.

, 1977b. Upper Cretaceous planktonic foraminifera from the subsurface of the Atlantic Coastal Plain of New Jersey. J. Foraminiferal Res., 7:165-187.

Romein, A. J. T., 1979. Lineages in early Paleogene calcareous nannoplankton. Utrecht Micropaleontol. Bull., 22:1-231.

Sissingh, W., 1977. Biostratigraphy of Cretaceous calcareous nannoplankton. Geol. en Mijnbouw, 56:37-65.

Wind, F. H., 1979. Late Campanian and Maestrichtian calcareous nannoplankton biogeography and high-latitude biostratigraphy $[\mathrm{Ph} . \mathrm{D}$. dissert.]. Florida State University, Tallahassee.

Wise, S. W., 1977. Chalk formation: early diagenesis. In Anderson, N. R., and Malahoff, A. (Eds.), The Fate of Fossil Fuel $\mathrm{CO}_{2}$ in the Oceans: New York (Plenum), pp. 717-739.

Worsley, T. R., 1974. The Cretaceous-Tertiary boundary event in the ocean. In Hay, W. W. (Ed.), Studies in Paleo-oceanography. Soc. Econ. Paleontol. Mineral. Spec. Publ., 20:94-125.

Date of Initial Receipt: 1 August 1985

Date of Acceptance: 11 June 1986

\section{APPENDIX}

Calcareous Nannofossils Considered in This Chapter (in alphabetical order of species epithets)

\section{Paleogene}

Chiphragmalithus acanthodes Bramlette and Sullivan, 1961

Chiasmolithus altus Bukry and Percival, 1971

Sphenolithus anarrhopus Bukry and Bramlette, 1969

Discoaster barbadiensis Tan Sin Hok, 1927
Chiasmolithus bidens (Bramlette and Sullivan) Hay and Mohler, 1967

Braarudosphaera bigelowii (Gran and Braarud) Deflandre, 1947

Rhomboaster bitrifida Romein, 1979

Zygrhablithus bijugatus (Deflandre) Deflandre, 1959

Discoaster binodosus Martini, 1958

Discoasteroides bramlettei (Stradner) Bramlette and Sullivan, 1961

Tribrachiatus bramlettei (Brönnimann and Stradner) Proto Decima et al., 1975 (morphotype B)

Chiphragmalithus calathus Bramlette and Sullivan, 1961

Chiasmolithus californicus (Sullivan) Hay and Mohler, 1967

Neochiastozygus chiastus (Bramlette and Sullivan) Perch-Nielsen, 1971

Micrantholithus concinnus Bramlette and Sullivan, 1961

Heliolithus conicus Perch-Nielsen, 1971

Chiasmolithus consuetus (Bramlette and Sullivan) Hay and Mohler, 1967

Tribrachiatus contortus (Stradner) Bukry, 1972

Rhabdosphaera creber Deflandre in Deflandre and Fert, 1954

Rhomboaster cuspis Bramlette and Sullivan, 1961

Chiasmolithus danicus (Brotzen) Hay and Mohler in Hay et al., 1967

Campylosphaera dela (Bramlette and Sullivan) Hay and Mohler, 1967

Discoaster diastypus Bramlette and Sullivan, 1961

Braarudosphaera discula Bramlette and Riedel, 1954

Ellipsolithus distichus (Bramlette and Sullivan) Sullivan, 1964

Pontosphaera distincta (Bramlette and Sullivan) Roth and Thierstein, 1972

Discoaster distinctus Martini, 1958

Neococcolithes dubius (Deflandre) Black, 1967

Sphenolithus editus Perch-Nielsen, 1978

Discoaster elegans Bramlette and Sullivan, 1961

Campylosphaera eodela Bukry and Percival, 1971

Chiasmolithus eograndis Perch-Nielsen, 1971

Coccolithus eopelagicus (Bramlette and Riedel) Bramlette and Sullivan, 1961

Micrantholithus entaster Bramlette and Sullivan, 1961

Pontosphaera exilis (Bramlette and Sullivan) Romein, 1979

Chiasmolithus expansus (Bramlette and Sullivan) Gartner, 1970

Discoaster falcatus Bramlette and Sullivan, 1961

Micrantholithus flos Deflandre in Deflandre and Fert, 1954

Coccolithus formosus (Kamptner) Wise, 1973

Discoaster gemmifer Stradner, 1961

Discoaster germanicus Martini, 1958

Chiasmolithus gigas (Bramlette and Sullivan) Radomski, 1968

Rhabdosphaera gladius Locker, 1967

Chiasmolithus grandis (Bramlette and Riedel) Radomski, 1968

Discoaster helianthus Bramlette and Sullivan, 1961

Rhabdosphaera inflata Bramlette and Sullivan, 1961

Markalius inversus (Deflandre) Bramlette and Martini, 1964

Fasciculithus involutus Bramlette and Sullivan, 1961

Table 5. Distribution of calcareous nannofossils, Well QA-BG 54, Maryland Coastal Plain.

\begin{tabular}{|c|c|c|c|c|c|c|c|c|c|c|c|c|c|c|c|}
\hline Age & $\begin{array}{c}\text { Foraminifer } \\
\text { zones } \\
\text { (Olsson, } \\
\text { pers. } \\
\text { comm.) }\end{array}$ & $\begin{array}{l}\text { Nannofossil } \\
\text { zones }\end{array}$ & $\begin{array}{c}\text { Sample } \\
\text { interval } \\
\text { (ft.) }\end{array}$ & 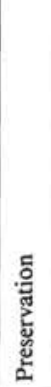 & 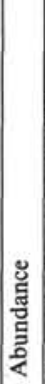 & 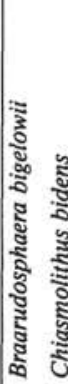 & 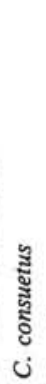 & ฏัँ & 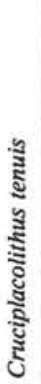 & 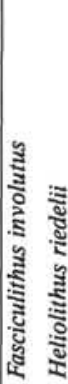 & 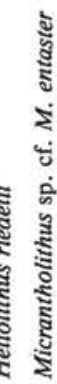 & 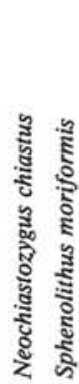 & 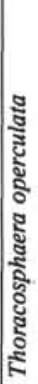 & 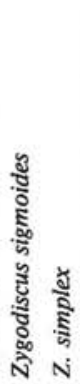 & 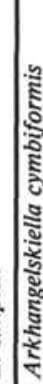 \\
\hline \multirow{3}{*}{ Paleocene } & P3b & CP4 & $245-247$ & ME & C & C & $\mathrm{F}$ & F & $\mathbf{R}$ & F $\quad r$ & $r$ & F R & & $\mathbf{R}$ & \\
\hline & P3a & $\mathrm{CP} 3$ & $249-250$ & $P$ & $\mathrm{~F}$ & C & & & $\mathrm{R}$ & & & & & & \\
\hline & P1b & CP1 & $\begin{array}{l}260-265 \\
276-277 \\
290-293\end{array}$ & $\begin{array}{l}\mathrm{P} \\
\mathrm{M} \\
\mathrm{P}\end{array}$ & $\begin{array}{l}\mathrm{F} \\
\mathrm{C} \\
\mathrm{C}\end{array}$ & F & & & $\begin{array}{l}\mathrm{R} \\
\mathrm{F} \\
\mathrm{R}\end{array}$ & & R & R & & $\begin{array}{ll}R & R \\
C & \\
C & \end{array}$ & $r$ \\
\hline
\end{tabular}

Note: Abundance is characterized by V, very abundant; C, common; F, few; R, rare; B, barren, EB, essentially barren. For preservation, $\mathrm{P}$, poor; M, moderate; G, good, E, etched; O, overgrown. Lowercase letters indicate material considered to be reworked, 


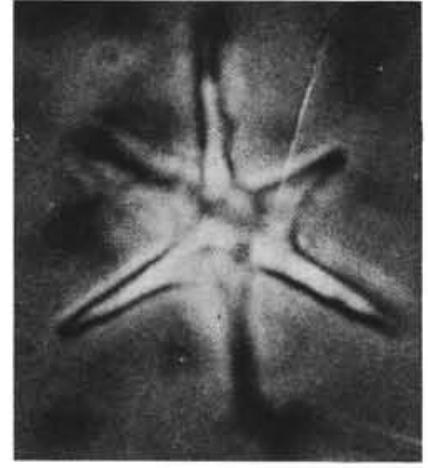

Figure 5. Tribrachiatus bramlettei (Brönnimann and Stradner) morphotype B, $\times 2240$, Leggett Well, Sample 550, phase-contrast light.

Neochiastozygus junctus (Bramlette and Sullivan) Perch-Nielsen, 1971 Heliolithus kleinpellii Sullivan, 1964

Discoaster kuepperi Stradner, 1959

Discoaster lenticularis Bramlette and Sullivan, 1961

Discoaster lodoensis Bramlette and Riedel, 1954

Ellipsolithus macellus (Bramlette and Sullivan) Sullivan, 1964

Discoaster mediosus Bramlette and Sullivan, 1961

Discoaster mirus Deflandre in Deflandre and Fert, 1954

Discoaster mohleri (Stradner) Bukry and Percival, 1971

Lophodolithus mochlophorus Deflandre in Deflandre and Fert, 1954

Sphenolithus moriformis (Brönnimann and Stradner) Bramlette and Wilcoxon, 1967

Pontosphaera multipora (Kamptner) Roth, 1970

Discoaster multiradiatus Bramlette and Riedel, 1954

Lophodolithus nascens Bramlette and Sullivan, 1961

Discoaster nobilis Martini, 1961

Chiasmolithus oamaruensis (Deflandre) Hay, Mohler, and Wade, 1966

Thoracosphaera operculata Bramlette and Martini, 1964

Lithostromation operosum (Deflandre) Bybell, 1975

Tribrachiatus orthostylus Shamrai, 1963

Pontosphaera pectinata (Bramlette and Sullivan) Sherwood, 1974

Coccolithus pelagicus (Wallich) Schiller, 1930

Lithostromation perdurum Deflandre, 1942

Rhabdosphaera perlongus Deflandre in Grassé, 1952
Pontosphaera plana (Bramlette and Sullivan) Haq, 1971

Zygodiscus plectopons Bramlette and Sullivan, 1961

Sphenolithus primus Perch-Nielson, 1971

Pontosphaera pulchra (Deflandre) Romein, 1979

Nannotetrina quadrata (Bramlette and Sullivan) Bukry, 1973

Sphenolithus radians Deflandre, 1952

Heliolithus riedelii Bramlette and Sullivan, 1961

Lophodolithus reniformis Bramlette and Sullivan, 1961

Discoaster saipanensis Bramlette and Reidel, 1954

Reticulofenestra samodurovii (Hay, Mohler, and Wade) Roth, 1970

Fasciculithus schaubi Hay and Mohler, 1967

Zygodiscus sigmoides Bramlette and Sullivan, 1961

Zygodiscus simplex (Bramlette and Sullivan) Hay and Mohler, 1967

Lithostromation simplex (Klumpp) Bybell, 1975

Chiasmolithus solitus (Bramlette and Sullivan) Locker, 1968

Discoaster sublodoensis Bramlette and Sullivan, 1961

Discoaster tanii Bramlette and Riedel, 1954

Blackites tenuis (Bramlette and Sullivan) Bybell, 1975

Cruciplacolithus tenuis Hay and Mohler

Fasciculithus tympaniformis Hay and Mohler, 1967

Reticulofenestra umbilica (Levin) Martini and Ritzkowski, 1968

Micrantholithus vesper Deflandre in Deflandre and Fert, 1954

Rhabdosphaera vitreus Deflandre in Deflandre and Fert, 1954

Discoaster woodringii Bramlette and Riedel, 1954

\section{Cretaceous Species Considered for Site $\mathbf{6 0 5}^{\mathbf{1}}$}

Reinhardtites anthophorus (Deflandre) Perch-Nielsen, 1968

Watznaueria barnesae (Black) Perch-Nielsen, 1968

Lucianorhabdus cayeuxii Deflandre, 1959

Prediscosphaera cretacea (Arkhangelsky) Gartner, 1968

Arkhangelskiella cymbiformis (Arkhangelsky) Deflandre, 1952

Microrhabdulus decoratus Deflandre, 1959

Tetrapodorhabdus decorus (Deflandre and Fert) Wind and Wise, 1977

Micula decussata Vekshina, 1959

Reinhardtites elegans (Gartner) Wise, 1983

Nephrolithus frequens Gorka, 1957

Marthasterites inconspicuus Deflandre, 1959

Ragodiscus splendens (Deflandre) Verbeek, 1977

Eiffellithus turriseiffeli (Deflandre in Deflandre and Fert) Reinhardt, 1965

\footnotetext{
${ }^{1}$ Exclusive of any previously listed for the Paleogene.
} 